\title{
Enhancing Sustainable Development Goals through The Provision of Decent Work to Minimize Inequality: A Comparative Study of Bangladesh and Indonesia
}

\author{
Syera Anggreini Buntara ${ }^{1, *}$, Anggia Utami Dewi ${ }^{1}$, Dadan Suryadipura ${ }^{1}$ \\ ${ }^{1}$ International Relations Study Program, Faculty of Social and Political Sciences, Padjadjaran University, Sumedang - \\ Indonesia
}

\begin{abstract}
Globalization has helped countries to accelerate its growth and reduce poverty rate, particularly Bangladesh and Indonesia. Both countries started to reduce trade barrier and open up to globalization in around 1980s to 1990s and has enjoyed impressive growth since then. However, this impressive growth does not come without risks. Globalization has forced labors to meet the production target while neglecting safety measure, causing high work-related accidents in both countries. Statistics show an increase in the number of work-related accident year by year in both countries. In addition to the labor welfare condition, studies also show how actually even with decrease of global poverty rate, globalization increases inequalities. This paper analyzes globalization effect to labor welfare and inequality in Bangladesh and Indonesia by using comparative study approach. This paper also aims to provide solutions in minimizing inequality and enhancing labor welfare through the provision of decent work in accordance to Sustainable Development Goals (SDGs).
\end{abstract}

Keywords: Globalization, Inequality, Labor Welfare, Work-Related Accidents, SDGs, Decent Work

\section{Introduction}

Globalization is proven successful in enhancing economic growth, especially in Bangladesh and Indonesia. In Bangladesh case, it experienced rapid economic growth since it liberalized and integrated its markets to global economy in 1990s. Manufacturing sector or fast fashion industry is one of the sectors that contributes most to the GDP of Bangladesh [1]. The contribution of manufacturing industry to Bangladesh's GDP was rising from 13.4 percent in 1990 , to 15.2 percent in 2000 , and 17.4 percent in 2014 [2]. Fast fashion industry produced \$28billion-a-year worth of garment export, making Bangladesh as the second biggest exporter of garment after China in the world. Fast fashion industry also accommodates job for about 4 million labors in Bangladesh [3].

However, rapid economic growth induced by globalization does not always mean prosperity. Besides rising employment rate, fast fashion industry is the only sector that receives most blame for insecurity and unprosperity among labors in
Bangladesh. Many work-related accidents have occurred in the last three decades. To mention some of the accidents - Factory fire at Saraka Garment (1990), Factory collapse Savar (2005), Factory fire in Cittagong (2006), Factory fire Garib \& Garib (2010), Factory fire That's it Sportswear (2010), and Factory fire at Tazreen Fashion (2012) - with total victims of 321 people killed (Deadly Secrets, 2012: 27-29). The worst work-related accident in Bangladesh was in 2013 when the Rana Plaza Factory collapsed, resulting in 1,134 labors died.

Moving to Indonesia's case, Indonesia started to remove trade barriers in 1970s and implement trade liberalization package in 1986. The liberalization effort contributed to a rise in Indonesia's GDP growth from around 3\% before 1970 s to a range of $3 \%$ to $11 \%$ after 1970 s [4]. Globalization also reduced unemployment rate as could be seen from a yearly increase in total employment provided by both foreign and domestic enterprises. Between 1980 and 1990, total employment in Indonesia grew by $2.9 \%$ per year and this added jobs for around 18 million new labors [5].

\footnotetext{
${ }^{*}$ Corresponding author email syera15001@mail.undip.ac.id
} 
According to Badan Pusat Statistik, total employment rose from 2.66 million in 1990 to 4.12 million in 1998 [6]

However, despite a rise in GDP and total employment, labors' insecurity and unprosperity also happen in Indonesia. Although work-related accidents in Indonesia are not as massive as those happening in Bangladesh, work-related accidents in Indonesia happen quite intensively. According to Badan Penyelenggara Jaminan Sosial (BPJS) Ketenagakerjaan, the number of work-related accidents in Indonesia in 2015 reached 105,182 cases with total death of 2,375 people [7]. Industry contributing the highest to work-related accidents is manufacturing and construction with both manufacturing and construction industry contributes to around $32 \%$ each [8].

\section{Methodology}

This paper will analyze the correlation between globalization and work-related accidents in Bangladesh and Indonesia by using comparative study approach. This paper aims to develop decent work as solutions to inequality and labor welfare, particularly in work-related accidents case, in accordance to Sustainable Development Goals (SDGs).

\section{Discussion}

Globalization is closely related to capitalism. Dani Rodrik defines globalization as the worldwide extension of capitalism, with the two processes being so deeply intertwined that one cannot discuss the future of one without considering the future of the other [9]. Capitalism is an economic system which allows private actors to own and control their poverty in accordance with their interests. Capitalism has become a widespread global phenomenon marked by the expansion of various multinational corporations around the world.

One of capitalism pillars is competition. This means that corporations will try to increase their excellence in providing better and cheaper products or services in order to survive and win the competition [10]. To provide cheap products and services, corporations need to minimize production cost. This sometimes put labors at risk because they were forced to extend their shift of work to meet production target with a minimum wage. Moreover, for the sake of minimizing production cost, corporations sometimes also neglect the responsibility to provide a safe working condition for their labors. One of them included environment, which gives much influence on labour's health condition. This condition is still becoming an issue because improper food, sanitation, and environment would affect labour's work result and effectivity. These conditions happen in both Bangladesh and Indonesia.

In Bangladesh's Rana Plaza case, both the government and the factory owner failed to protect labors safety as they chased multinational corporations to keep investing in Bangladesh by maintaining low production cost. To maintain low production cost, the factory owner violated the building safety standard. He added several floors illegally to boost clothing production. The illegal floor addition built on a weak structure coupled with poor quality of factory building material and the overload of machine in the factory led the loadbearing columns to crack apart. With this sign of disaster, the factory supervisor still forced labors to work to meet production target and threatened them a wage cut if they did not continue working. Afraid of getting wage cut, the labors came to the factory to work the next morning. When they were working, the factory building shook and started to ruin. The labors had no time to escape from the building, causing more than 1,134 labors dead and 2,500 injured [11].

In Indonesia's Morowali case, work-related accidents reoccurred frequently. In 2013, a truck containing nickel ore was flipped over. In 2014, a Chinese labor fell from construction column. In 2016, a container exploded and fell on a Chinese labor. In 2017, an Indonesian labor was crushed by bulldozer and another labor was hit by hot material [12]. The frequent various work-related accidents in Morowali is due to inadequate safety facilities. Many workers are not equipped with anti-fire clothing. Work-related accidents in Morowali are also driven by pressure to meet production target. Morowali implements bonus system through which labors will get incentive as much as 300,000 rupiahs per day if they can transport nickel material up to 20 times a day. However, this system is not accompanied by labors' safety protection, making labors prone to work-related accidents [13].

According to ILO, decent work is a key to combat poverty, minimize inequality, and realize Sustainable Development. The notion decent work is stated as ILO's primary goal in 1999 ILO DirectorGeneral Report to the International Labour Conference. Decent work highlights four elements which are: (1) employment, (2) social security, (3) labors' rights, and (4) social dialogue. Social security means that labors deserve safe working condition and adequate wage as well as are protected from the risk of losing income. While labors' rights and social dialogue refer to various labors' rights, for instance freedom of association and nondiscrimination in work [14]. Decent work is embodied in point 8 Sustainable Development Goals with the title of "Promoting sustained, inclusive and 
sustainable economic growth, full and productive employment and decent work for all".

The UN Department of Economic and Social Affairs classified inequality into two, which are inequality of outcome and inequality of opportunity. Inequality of outcome is a condition when individuals' standard of living is not equal, for example inequality in income, education, and health. Inequality of opportunity is a condition when individuals' do not have the same opportunity when it comes to getting jobs for reasons of race, gender, religion, disability, and so forth [15].

This paper will highlight the second element of decent work, which is social security, and will focus on providing solutions regarding inequality of opportunity, particularly on how the victims of work-related accidents can return to their work. In Indonesia, there has been a shift of direction in Employment Injury (EI) Scheme which formerly focused on claim management, now shifting to rehabilitation and return to work. This shows Indonesia's effort in creating an inclusive and integrated EI Scheme which comprises of prevention, rehabilitation, and compensation. BPJS Indonesia, as the institution responsible to handle social security issue, launched Return to Work (RTW) Program. This program assists work-related accident survivors both physically and mentally, including funding hospital care cost, and aims to equip the survivors with necessary skills to return to work [16].

However, there is a challenge when it comes to making RTW runs effectively. Director of Membership Expansion and Inter-Institution Relations BPJS said that BPJS is merely responsible in providing assistance in form of training for the survivors until they are well-prepared to return to work. He added that it is not within BPJS's responsibility to place the survivors in a work position [17]. This does not guarantee survivors with job and generates difficulty for the survivors in finding jobs as their previous job might not be suitable for them due to their disabilities.

Responding to this challenge, BPJS should expand its responsibility to include listing the jobs available and suitable for survivors as each survivor has different defect and skill. By listing the jobs, it will serve as guidance for BPJS to train survivors in skills necessary for the available jobs. Moreover, BPJS should also expand its form of assistance to not only training assistance, but also capital assistance. This will ensure that survivors of work-related accidents will have source of income whether it is from being employed in companies/institutions or becoming an entrepreneur.

There is lack of data concerning EI Scheme implementation and challenges in general in Bangladesh, yet if traced through the case of Rana Plaza collapse, it appears that the EI Scheme program has not worked effectively. This is supported by the latest data in 2014 which shows that $74 \%$ of Rana Plaza survivors had not returned to work because of physical disabilities, trauma, and employers' unwillingness ${ }^{18}$. Even if the survivors have gone back to work, they are still suffering from mental illness and trauma. Based on perception survey conducted in around 2016, 58.4\% of the survivors are still affected by psychosocial problems, $37.3 \%$ are stable, and only $4.3 \%$ have fully recovered. Executive Director of Bangladesh Institute of Labour Studies (BILS) said that no organization that can assess and follow up the psychological condition of all survivors. This is because in Bangladesh mental health is not a priority or for some people it is considered as taboo ${ }^{19}$.

Understanding the challenges, Bangladesh government along with NGOs can cooperate to raise public awareness regarding the importance of mental health. This could be done by conducting campaign and education, as well as incorporating the message of the importance of mental health in arts, such as music and video.

\section{Conclusion}

Globalization promotes global capitalism which competes in making production cost as efficient as possible to win market competition. The attempt to minimize production cost sometimes is not accompanied by effort to protect labors safety and welfare which results in numerous work-related accident cases. The survivors of work-related accident, especially those with disabilities, may find it hard to get a job. This depicts inequality of opportunity when the survivors of work-related accidents are discriminated or marginalized in labor market.

In order to minimize inequality and promote sustainable development, it is necessary for government and companies to realize decent work. In this case, decent work takes form of providing a safe working condition for all labors. One of safe working condition elements is social security. Government should promote inclusivity in workplace by developing Employment Injury Scheme which will rehabilitate and integrate the survivors in workplace.

Both Indonesia and Bangladesh have EI Scheme under which the survivors of work-related accidents are provided medical treatments as well as rehabilitation and training to prepare them to return to work. In Indonesia, EI Scheme is developed and implemented by BPJS through special program called Return to Work. This program runs well, though there are some aspects needed to be reformed regarding BPJS responsibility and form of assistance. In term of preparing the survivors to 
return to work, BPJS should expand its responsibility not only to provide training for the survivors, but also to list several job vacancies which are open to the survivors. This is to guide BPJS in equipping the survivors with skills that are necessary for job vacancies, hence this will guarantee that the survivors that they will return to work upon the completion of training. In term of form of assistance, BPJS should expand its form of assistance to include providing capital to the survivors, particularly to those who are not able to get job after completing training. In other word, BPJS responsibility is not limited to preparing the survivors with skills necessary to return to work, but also ensuring that the survivors will have source of income whether from being employed or becoming entrepreneurs.

Although there are not much data regarding the implementation of Bangladesh EI Scheme, especially the scheme which will rehabilitate the survivors, it appears that Bangladesh EI Scheme has not worked effectively because of the society paradigm that considers mental health as taboo. Thus, cooperation between government and NGOs is necessary to raise awareness of the importance of mental health. Only by raising the awareness of mental health, the government can take further measures in implementing effective rehabilitation program for the survivor of work-related accidents and ensure they can return to work.

\section{References and Notes}

1. Bangladesh government, Chapter 8: Industry, Retrieved May 13, 2017. http://www.mof.gov.bd/ (2013).

2. S. Ahmed, "Rise in manufacturing sector's contribution to GDP". The Independent Bangladesh, Retrieved May 13, 2017 from http://www.theindependentbd.com/home/print news/74702 (2016).

3. P. Jayapal, "Can Western companies put an end to Bangladesh factory disasters?", Reuters, Retrieved April 14, 2017 from http://blogs.reuters.com (2013).

4. I. Simorangkir, "The Openness and Its Impact to Indonesian Economy: A SVAR Approach". Paper presented at the Graduate Program in Economic Development's 50 ${ }^{\text {th }}$ Anniversary Conference November 9-11, 2006, Retrieved October 12, 2017, from https://as.vanderbilt.edu/econ//conference/gpe d-conference-06/papers/iskandar.pdf (2006).

5. F. Iqbal et al., "Deregulation and Development in Indonesia", Westport, Connecticut London: Praeger (2002).

6. R. Robertson et al., "Chapter 7: Globalization and Working Conditions: Evidence from Indonesia" in Globalizarion, Wages, and the Quality of Jobs Five Country Studies.
Washington DC: The World Bank, Retrieved October $\quad 12, \quad 2017$ from https://openknowledge.worldbank.org (2009).

7. A. Ramadhiani, "Kecelakaan Kerja di Indonesia Tercatat 105.182 Kasus, 2016". KOMPAS, Retrieved October 12, 2017 from http://properti.kompas.com (2016).

8. A. N. Arimah, "Kecelakaan Kerja di Indonesia Terbanyak di Sektor Konstruksi dan Manufaktur", Republika, Retrieved October 12, 2017 from http://www.republika.co.id (2015).

9. D. Rodrik, "The Globalization Paradox: Democracy and the Future of the World Economy”, NY: W. W. Norton \& Co, New York (2011).

10. J. Tucker, "Five Pillars of Economic Freedom", Laissez Faire Books, Retrieved October 12, 2017 from https://lfb.org/fivepillars-of-economic-freedom (2012).

11. ILO, "Employment injury insurance Challenges in building a new scheme", Retrieved October 13, 2017 from http://www.social-protection.org (2016).

12. Yayasan Tanah Merdeka, "Lagi-lagi Kecelakaan Kerja Terjadi di PT. IMIP, 2017”, Retrieved October 13, 2017 from http://ytm.or.id (2017).

13. Berdikari Online, "Ytm: Perusahaan Nikel Di Morowali Abaikan Keselamatan Kerja, 2013", Retrieved October 13, 2017 from http://www.berdikarionline.com (2013).

14. D. Gai, "Decent work: Concepts, models and indicators", International Institute for Labour Studies, Geneva, 2002, Retrieved October 13, 2017 ,

http://hdrnet.org/131/1/Decent_work_concept s models and indicators.pdf (2002).

15. UN Department of Economic and Social Affairs. Concept of Inequality, October 21, 2015, Retrieved October 12, 2017 from http://www.un.org (2015).

16. BPJS Ketenagakerjaan, "Jaminan Kecelakaan Kerja”, n.d. Retrieved October 13, 2017. http://www.bpjsketenagakerjaan.go.id (n.d.).

17. Hukum Online, "Ini Perlu dilakukan agar Permenaker Return to Work Efektif", Retrieved October 13, 2017 from http://www.hukumonline.com (2016).

18. S. Hamadi, "Why Bangladesh's Rana Plaza survivors are back at work", CS Monitor, Retrieved October 14, 2017 from https://www.csmonitor.com (2014).

19. S. S. Preetha, "Living with the ghost of Rana Plaza", The Daily Star, Retrieved October 14, 2017 from http://www.thedailystar.net (2017). 